\title{
O INIMIGO SIDERAL: A MONSTRUOSIDADE NAS FICÇÕES CINEMATOGRÁFICAS COM SERES ALIENÍGENAS
}

Marcio Markendorf (UFSC)

Recebido em 13 fev 2017. Marcio Markendorf possui Graduação em Letras pela Aprovado em 20 abr 2017.

Universidade Federal de Mato Grosso do Sul (2003) e Doutorado Direto em Literatura, concentração em Teoria da Literatura, pela Universidade Federal de Santa Catarina (2009). Atualmente é Professor Adjunto do Departamento de Artes da Universidade Federal de Santa Catarina e leciona no Curso de Bacharelado em Cinema e no Programa de Pósgraduação em Literatura. É membro do Conselho Científico da Revista Anuário de Literatura, publicação da Pós-Graduação em Literatura da UFSC, e da Revista Rascunhos Culturais, publicação do curso de Letras da UFMS, CPX, e da Revista Estação Literária, periódico da Pós-Graduação em Literatura da UEL. Está vinculado aos Grupos de Pesquisa Literatura e Memória e Arte e Mestiçagens poéticas. É membro do Núcleo Literatual - Estudos Feministas e Pós-coloniais de Narrativas da Contemporaneidade. Tem experiência na área de Letras e Cinema, com ênfase em Teoria da Literatura, Escrita Criativa e Gêneros Cinematográficos, atuando, pesquisando e publicando nas linhas de pesquisa Ficções da Realidade e Literatura e Memória.

Resumo: Historicamente aquele que vem de outra localidade, o 'Outro, é percebido, em primeira 
instância, sob o jugo avaliativo do exótico e, em segundo momento, como uma alteridade potencialmente ameaçadora, um inimigo. Se no imaginário fantasioso e medieval da terra incognita, os limites do mundo conhecido eram habitados por raças de monstros, 0 que se pode dizer das fronteiras não mapeadas dos territórios extraplanetários? Este ensaio pretende circunscrever alguns dos qualificativos monstruosos comumente associados aos seres provenientes do espaço sideral, com ênfase na convergência do estético, do ético e do político. O texto privilegia as narrativas cinematográficas para analisar o aspecto físico, o caráter parasitário, o instinto predatório e o imperialismo invasor dos extraterrestres.

Palavras-chave: Alienígenas; Monstruosidade; Cinema.

Abstract: Historically, the one that comes from another location (The Other) is evaluated, at first, under the light of the exotic and, next in order, as a potentially threatening otherness. If in the fantastic medieval imagery of terra incognita, races of monsters inhabited the borders of the known world, what is to be said about uncharted, outer-space territories? This essay aims at circumscribing some monstrous characteristics commonly associated with extraterrestrial beings, with emphasis on the convergence between aesthetic, ethical and political aspects. The text takes as example film narratives seeking to analyze the extraterrestrials in terms of their monstrous physicality, parasitic character, predatory instincts and imperialist motivations.

Key words: Extraterrestrials; Monsters; Films.

\section{LUGARES-COMUNS DA FICÇÃO CIENTÍFICA}

Se de repente nos fosse revelado esse segredo da grande vida extraterrestre, que assombro! (Guy de Maupassant, O homem de marte) 
Em um artigo escrito em meados de 1934, Notas sobre ficção interplanetária, H. P. Lovecraft (2012) refuta certos lugares-comuns da cientificção de sua época e denuncia a ausência de caráter artístico em boa parte das obras escritas, resultado atribuído por ele a certa vulgarização, superficialidade e infantilidade no tratamento de relatos envolvendo viagens espaciais e raças siderais. Para o consagrado escritor, um relato do impossível não poderia ser apresentado como uma narrativa ordinária, marcada por ações objetivas e emoções convencionais. Diante de um evento com capacidade para desafiar os limites conhecidos pelo ser humano e a própria verossimilhança do relato - a partir da proposição do prodígio, da anormalidade e do fenômeno -, o aspecto causal deveria recuar por meio de um realismo meticuloso, da exploração atmosférica e do tratamento emocional. Não haveria vivacidade em uma narrativa sem paleta de emoções condizentes, sobretudo com viajantes sob o espanto de estarem longe da Terra.

Da crítica lovecraftiana (LOVECRAFT, 2012) alguns pontos merecem destaque por serem encontrados em um grande número de ficções: a atmosfera vazia de espanto em relação aos viajantes do espaço, efeito provocado por um tratamento ordinário do extraordinário; uso de personagens pouco realistas e humanizados, frequentemente liderados pelo cientista, sua linda filha e o assistente inescrupuloso; o aprendizado fácil de línguas alienígenas no contato entre os nativos das diferentes raças; o vasto emprego da telepatia como saída para linguagem comunicativa; a intervenção humana em assuntos políticos dos mundos alienígenas; o interesse amoroso por um príncipe ou princesa antropomórfica; estereotipadas destruições em massa 
por meio de naves espaciais e raios laser; representação das civilizações alienígenas como mais evoluídas que a nossa (quando o preferível, como defendido pelo escritor, seriam graus diferentes de desenvolvimento). Aliás, em relação a este último ponto é que se apoia o caráter invasor-destruidor do horror cósmico tradicional, construtor de uma narrativa do choque, do embate bélico e da mensuração de forças hostis.

Autor de narrativas alienígenas consagradas pela densidade no tratamento e pela inovação tais como $O$ chamado de Cthulhu, de 1926, e A cor que caiu do espaço, de 1927, Lovecraft preocupou-se em expressar o espanto e o esfacelamento das certezas humanas. No artigo Notas sobre a escritura de contos fantásticos, publicado pela primeira vez em 1937, o autor se debruça sobre aspectos do horror cósmico, um eixo teórico que dominou sua práxis literária e mesmo sua verve teórica, como já havia demonstrado $O$ horror sobrenatural em literatura, obra teórica de 1927. Segundo o ponto de vista defendido (LOVECRAFT, 2011), a atmosfera deve ser o grande objeto de desejo da ficção fantástica, não propriamente a ação, pois seria impossível realçar os acontecimentos puros sem a atmosfera e a ambientação apropriadas. O espaço cósmico infinito, por sua singularidade, deveria obrigatoriamente produzir o horror cósmico (LOVECRAFT, 2008), sensação emocional cujo aporte é o desconhecido, o não familiar, o sinistro, o não domesticado, o intocado, o amedrontador, o exótico. O horror cósmico desconstruiria as convicções (científicas) e as leis naturais e/ou reconhecidas até o momento do portento, de modo a estimular emoções incontroláveis. Por essa relação de causa-efeito, Lovecraft acusa de charlatanismo ficcional imaturo as narrativas que adotam 
a perspectiva ordinária e indiferente para o extraordinário. A título de exemplo, vale apontar ao menos duas narrativas de autores icônicos da ficção científica, Jules Verne e H. G. Wells, cujas obras contém traços embrionários do imaginário trivial de ficções interplanetárias referido por H. P. Lovecraft.

O romance de aventura Viagem ao redor da Lua, de Jules Verne, datado de 1865, certamente não teria sido aprovado no crivo do horror cósmico de H. P. Lovecraft, pois a "fantasia científica" apresenta uma jornada extraordinária do modo mais simplista possível: um projétil tripulado por três homens, dois cachorros, algumas galinhas, equipado com camas comuns e, dentre outros víveres, chá e vinho de provisão, parte para o encontro com os chamados selenitas (nome derivado do grego selēnē, palavra para lua) - supostos habitantes do astro lunar. Com a estrutura episódica própria das narrativas de aventura, Verne procura imprimir um caráter verossímil à primeira viagem espacial da literatura por meio de um texto cientificamente bastante didático (ver capítulos como Um pouco de álgebra, Perguntas e respostas, Fantasia e realidade: VERNE, 2005), mas que não aprofunda, radicaliza ou desconstrói nenhum conhecimento científico da época de publicação do livro. Os diálogos dos tripulantes constituem o principal recurso de inserção de elementos de ciência na trama, muito embora para o leitor contemporâneo revelem-se bastante naïve, cômicos e até terrivelmente equivocados. Ademais, Jules Verne nos apresenta astronautas que partem para uma jornada sem instrumentos de navegação e da qual ninguém sabe como regressar - tudo dependeria das condições a serem encontradas na Lua e, sobretudo, das forças do acaso. Logo, não se pode negar 
que o empreendimento apela para o significado convencional da aventura, uma empresa de risco e perigo, uma vez que se trata de uma viagem ambiciosa e certamente suicida.

O grande mérito da narrativa de Verne talvez seja - crítica comum à ficção científica - o de antecipar elementos do futuro histórico: os norte-americanos são representados como os primeiros a terem chegado à Lua, impulsionados por uma política notadamente neocolonial. Conforme declara um dos personagens, a viagem tinha como propósito tornar o satélite lunar mais um dos estados norte-americanos, colonizando-o, ocupando-o e levando aos selenitas os ideais da civilização se acaso ainda fossem bárbaros. Por outro viés, a mensagem parece reverberar a ideologia do Destino Manifesto, responsável pelo selvagem avanço em direção ao oeste e pela cruel marcha civilizatória sobre os cadáveres dos povos indígenas. Felizmente, na fábula de Verne, o projétil apenas circulou ao redor do destino espacial, não observando nenhum tipo de ruína ou construção que documentasse a existência anterior ou presente de formas complexas de vida.

Em 1901, H. G. Wells publicaria Os primeiros homens da Lua, ficção espacial que se apropria do mote de Verne, inclusive citando a obra do francês na narrativa, para apresentar outra versão da viagem ao astro lunar. Desta vez (WELLS, 1985) o leitor é apresentado a uma dupla de viajantes cuja vontade de exploração e de conquistas leva à descoberta da civilização subterrânea dos selenitas. O narrador da trama é um homem de negócios falido que, percebendo em um vizinho próximo, um extravagante cientista, a possibilidade de enriquecimento com a invenção de uma nova substância, a cavorita, acaba sendo enredado pelo entusiasmo 
por uma possível jornada espacial. O ponto de vista escolhido para narrar a trama confere à história de Wells um caráter de "fantasia científica" similar ao projeto de Verne, sobretudo porque o narrador - neófito no universo da ciência - declara-se inapto a dar qualquer explicação científica dos eventos, preferindo focar-se apenas nas ações dos personagens. A dinâmica do extraordinário percebido de modo ordinário persiste também nesta obra, de modo que o encontro com florestas de cogumelos, bezerros lunares e mesmo com os selenitas não provoca nenhuma reação diferente daquela que um viajante em terras desconhecidas teria em relação à geografia nativa, física ou humana. Os elementos de maior ressonância da obra acabam por ser a descrição física dos selenitas, construída com base em uma semiótica antrozoomórfica para os extraterrestres - descritos como "homens-tamanduás" -, e o que se tornará um lugar-comum de muitas narrativas siderais, a civilização alienígena subterrânea.

Não seria de se estranhar, portanto, que o primeiro destino espacial a ocupar as câmeras de cinema, a Lua, tenha sido construído com base nos pressupostos do colonialismo ${ }^{1}$. Livremente inspirado nos romances de Jules Verne e de H. G. Wells, o cineasta Georges Méliès realizou, em 1902, o curta-metragem Viagem à lua (Le voyage dans la lune) $)^{2}$, considerado um marco na história dos efeitos especiais da sétima arte. Nesse épico cósmico, um grupo formado pelo que parecem ser magos-cientistas pousa em território lunar e

1 Para saber mais sobre conteúdos colonialistas em narrativas com representações extraterrestres, conferir o trabalho Os reflexos do colonialismo em ficções alienígenas (MARKENDORF, 2015).

2 Mais tarde, em 1904, Méliès retorna ao tema das viagens espaciais com Viagem impossível (Le voyage à travers l'impossible), na qual propõe como destino nada mais nada menos do que a estrela magna, o Sol. 
encontra uma estranha e ofensiva raça, a dos selenitas. Os nativos lunares, apesar da natureza intersticial da sua morfologia ${ }^{3}$ - uma mistura de crustáceos, papagaios e esqueletos -, aparentavam ser governados por um rei/líder e regidos por leis tribais próprias. Não fosse pela insuficiência numérica, os terráqueos provavelmente teriam a pretensão de organizar o aparente caos, a anarquia e a barbárie daquele estranho povo, discurso de dominação/salvação próprio da ideologia dos sistemas coloniais.

Ademais, apesar do tom lúdico, quase infantil da película, outro traço da suposta inferioridade dos selenitas é demonstrado em razão da desintegração dos seus corpos quando golpeados pelos guarda-chuvas dos cientistas. Bastaria substituir o guarda-chuva por armas de verdade para nos darmos conta de que a narrativa, em última instância, retrata a violência alegórica dos conquistadores em relação ao povo nativo. Nas cenas finais, no retorno em fuga dos cientistas, um dos selenitas agarra-se à nave espacial. Na Terra, enquanto os viajantes são celebrados como heróis na sua volta, o estrangeiro lunar é apresentado à multidão como se fosse um entretenimento bizarro. Cena que nos lembra das antigas feiras de variedades, nas quais, há muito tempo atrás, também se expunham aos olhos dos europeus, tipos africanos, índios ou asiáticos como uma curiosa (e/ou monstruosa) criatura da natureza - tornando-os atrações de um zoológico humano.

Saturados dos clichês apontados por H. P. Lovecraft estariam também muitas produções posteriores ao pequeno artigo do 
escritor estadunidense (LOVECRACFT, 2012), fato que demonstra a longevidade dos lugares-comuns e de uma estrutura narrativa trivial para a cientificção. Ademais, convém destacar, Lovecraft rejeitava a construção de um caráter alegórico para as narrativas condição que esvaziaria a expressão emocional do horror cósmico, direcionando o plot narrativo para um tipo de representação histórico-cultural dos empreendimentos coloniais.

Na produção cinematográfica independente Mulheres-gato da Lua (Cat-women of the Moon, Arthur Hilton, 1953), por exemplo, uma expedição científica na Lua entra em contato com uma antiga civilização, a das mulheres-gato. As últimas remanescentes sobrevivem em galerias subterrâneas onde ainda há resquícios da atmosfera que cobria o satélite em outros tempos. Com características antropomórficas e dotadas de poderes telepáticos, a feminina raça lunar pretende sequestrar a nave expedicionária, submeter os homens da equipe ao seu domínio, viajar para Terra e colonizar nosso planeta a fim de salvar a própria raça. No entanto, uma das habitates lunares se apaixona por um dos terráqueos, revela os planos das comparsas, acaba sendo morta pela traição e, por suas ações anteriores, colabora para o retorno em segurança dos viajantes espaciais.

Argumento semelhante ao do filme acima descrito reaparece em Míssil para a Lua (Missile to the Moon, Richard E. Cunha, 1958) ao tratar de uma raça de mulheres telepatas - idêntica aos humanos, mas com a cor de pele azul - que vive nos subterrâneos de um satélite na iminência de ficar estéril e sem oxigênio. Segundo a história, um dos últimos homens havia partido para a Terra a fim de verificar as possibilidades de sobrevivência do povo lunar no planeta vizinho. 
Mais tarde, saberemos que o cientista responsável pela construção de um míssil espacial, financiado pela iniciativa privada e muito a frente do conhecimento militar no setor, era o selenita disfarçado de terráqueo. Não querendo submeter-se ao controle do Estado, desejoso de apropriar-se da tecnologia de ponta desenvolvida, o personagem parte em direção ao satélite lunar juntamente com dois foragidos da prisão ${ }^{4}$ e o jovem casal financiador da pesquisa. Naquele território, além de enfrentar aranhas gigantes e monstros de pedra, os viajantes precisam defender-se das mulheres selenitas e de seus poderes mentais de submissão.

O enredo de Míssil para Lua chega a ser cômico em certos momentos, como quando um dos viajantes avalia que dois vestígios muito simples - uma tocha apagada e marcas recentes de pegadas - constituem indícios óbvios de uma forma de vida avançada. Como demonstra a história das civilizações, não foi este um julgamento avaliativo dos navegantes europeus no Novo $\mathrm{Mundo}^{5}$, depois de encontrarem diferentes tribos indígenas, algumas ainda na fase neolítica de desenvolvimento, tal como boa parte das nações aborígenes brasileiras. A despeito do que poderia quase ser considerado um chiste, desde que se aplique o adjetivo "avançado" a idéia de forma biológica e não de grupo social, a civilização do

4 Um dos foragidos identifica que algumas pedras "sem valor", com mero caráter decorativo, encontrada com abundância no planeta, tratavam-se de diamantes, o que estimula a cobiça do terráqueo. Igual recurso da "riqueza ignorada" também aparece em Os primeiros homens da Lua, de Verne, pois as algemas dos selenitas eram feitas de ouro maciço. O tema dos metais abundantes e considerados triviais (ou sagrados) pelos nativos reaparece constantemente nas ficções alienígenas, com destaque para o centro da ação em Avatar (Avatar, James Cameron, 2009).

5 Merece destaque o estudo de Tzvetan Todorov (1983) acerca da conquista da América, trabalho no qual se discorre que o encontro entre conquistadores e íncolas ameríndios deveria ser compreendido na forma de uma alteridade simultaneamente afirmada e refutada. 
satélite lunar tanto de As Mulheres-gato da Lua quanto de Míssil para Lua mostrava-se bastante opulenta, com traços arquitetônicos romanos e gregos, com tecnologia superior à terrestre.

Como ilustram as narrativas destacadas, a viagem interplanetária só poderia acontecer na forma de um gesto de conquista/submissão e confrontação entre civilizações, especialmente quando se coloca em questão a diferença dos graus de desenvolvimento científico e tecnológico e, por extensão, de capacidade de dominação, salvação e "melhoramento" dos conquistados (sob o viés da doutrinação política e religiosa). Entretanto, o próprio conceito de civilização e de grau civilizatório, assim como o seu contraponto, a barbárie, são passíveis de questionamento, já que por meio da naturalização dessas pretensas leis regulamentares das sociedades é que muito se fez em relação às "raças" estrangeiras, distintas das europeias.

No século XIX, as concepções raciais e deterministas geográficas, biológicas e/ou ontológicas - reforçaram a ideia de que havia raças superiores e inferiores, discurso responsável por legitimar a escravidão de africanos e de outras etnias orientais e americanas por europeus. E, muito embora, o mundo tenha sofrido uma transformação cultural a ponto de considerar um crime o preconceito racial e a xenofobia ${ }^{6}$, o discurso ainda circula em meio a grupos radicais, da antiga Ku Klux Klan aos neo-nazistas e, sem dúvida, pode ser encontrado até nas "inocentes" ficções alienígenas. A vontade de dominação alien é construída não apenas em razão da necessidade de novos territórios para sobrevivência e conquista, mas por força de uma autopercepção deformada de civilização (ou

6 Acerca do darwinismo social presente em narrativas de ficção alienígena, ver $A$ reiteração fóbica do estrangeiro (MARKENDORF, 2015). 
raça) superior. A humanidade, por meio da ficção, em um misto de terror cósmico (diverso do horror cósmico lovecraftiano) e terror político, foi apresentada a uma situação de potencial submissão, fruto de um neocolonialismo interestelar, tendo como agressores iniciais o povo de um planeta próximo ao nosso.

Este ensaio, tomando como livre inspiração o artigo de Lovecraft (2012), Notas sobre ficção interplanetária, pretende circunscrever quatro representações típicas dos alienígenas na ficção audiovisual com vistas a problematizar o contexto mental que acabou por lapidar a imagem do visitante extraterreno no imaginário do século $\mathrm{XX}$.

\section{FIGURAÇõES TÍPICAS DA MONSTRUOSIDADE ALIENÍGENA}

A caracterização de algo como monstruoso é resultante de uma qualificação de natureza estética frequentemente atrelada a um julgamento de valor moral - tudo porque, segundo imaginário corrente, o monstro pertence ao campo do Mal e não ao do Bem (Cf. CARROL, 1999; NAZÁRIO, 1983; NAZÁRIO, 1998; JEHA, 2007; ECO, 2014). Em vista desta condição "natural" e "inata", podese defender que os componentes estéticos e éticos do monstro engendram em si um componente político. Se o Mal é algo a ser combatido, reprimido, expulso, segregado, marginalizado, impossível não perceber na tentativa de supressão desses seres uma forma de controle e, por isso, um exercício político. Enquanto produto da diferença, a entidade monstruosa provoca o desregramento de uma norma comunal, perturba a coesão de um domínio social coletivo e gera uma forte sensação de ameaça à ordem. A força dramática da aparência não normativa, produto 
do excesso e da exceção, admite, portanto, uma reação agressiva e defensiva contra aquilo que se rejeita. O sentimento de aversão, o discurso da violência, e o mecanismo da domesticação acabam por constituir formas de controle das transgressões. Nesse âmbito, o ser alienígena ou extraterrestre, por sua representação ficcional associada ao espaço desconhecido, excêntrico aos universos já mapeados, frequentemente ganha os contornos de uma entidade maligna, inimiga e invasora do planeta Terra.

A figuração típica do alienígena se defronta com questões radicais de alteridade - aquele que vê, percebe o Outro como exótico, estranho ou monstruoso. Na literatura dos relatos de viagem, o ponto de vista é invariavelmente daquele que parte em direção a outras fronteiras e depara-se com paisagens geográficas e humanas que lhe provocam estranhamento, condição que encerra um sentimento ambíguo: a consciência da própria identidade com base na tensão com a diferença. Enquanto um tipo muito particular de relato de viagem, sobretudo pela combinação com elementos do gênero da ficção científica, portanto, um relato de viagem intergaláctica, os filmes sobre alienígenas invertem o sentido tradicional e assumem o ponto de vista de quem recebe aquele que partiu. $\mathrm{O}$ olhar que está em operação não é o do viajante, mas o daquele que habita o destino final da viagem do viajado. Tal característica insinua menos um olhar do tipo etnográfico e mais um olhar xenófobo, porque o coletivo percebe o visitante como um corpo estranho à maioria e, por ser desconhecido, uma intimidação à normalidade local. Obviamente esse pensamento parte de uma perspectiva hipotética de "nação homogênea" ou, em outros termos, de uma crença na coesão e coerência de uma identidade 
nacional (no caso, uma identidade planetária única) ${ }^{7}$. Por essa razão, o extraterrestre, este tipo particular de estrangeiro, é sempre figurado sob o lastro de uma bizarria em qualquer uma das formas em que se apresente - antropomórficas, antropozoomórficas, zoomórficas, polimórficas ou amorfas.

Na ficção cinematográfica proliferam seres de duas ou mais cabeças, olhos gigantes, mãos com poucos dedos e garras afiadas, entidades rastejantes como amebas e toda uma sorte de espécies abomináveis, cheias de gosma e de aparência aterradora. A título de exemplificação, há os híbridos selenitas - humanoides com traços de crustáceos, papagaios e esqueletos - de Viagem à Lua (Le voyage dans la Lune, George Méliès, 1902); os trípodes marcianos de Guerra dos Mundos (The war of the worlds, Byron Haskin, 1953); as estranhas Mulheres-gato da Lua (Cat women of the Moon, Arthur Hilton, 1953); o exército de robôs de aço constantes em Vênus ataca a Terra (Target Earth, Sherman A. Rose, 1954); o rastejante olhotentacular no filme A Besta de um milhão de olhos (The beast with a million eyes, David Kramarsky e Roger Corman, 1955) e em The Crawling eye (The Trollenberg Terror, Quentin Lawrence, 1958); a raça de mulheres telepatas de pele azul em Míssil para Lua (Missile to the Moon, Richard E. Cunha, 1958); a forma de vida com braços de eletrodos e garras de jacaré surgida do Lodo verde (Green Slime, Kinji Fukasaku, 1968); o reptílico Alien, o oitavo passageiro (Alien, Ridley Scott, 1979); os humanoides anões, de cabeça avantajada e cérebro exposto no paródico Marte Ataca! (Mars attacks!, Tim Burton, 1996); e a raça alienígena invasora formada por ondas eletromagnéticas capazes de pulverizar os seres humanos em $A$

7 Conferir as discussões sobre narrativas da nação em: HALL, 2011; ANDERSON, 2008. 
hora da escuridão (The darkest hour, Chris Gorak, 2011), dentre outras possibilidades de uma numerosa iconografia. Na opinião dos ufólogos, entretanto, o tipo físico cristalizado pela cultura de massas é o grey, representado por uma forma humanoide, pele acinzentada, baixa estatura, cabeça avantajada, olhos enormes e sem esclerótica, sem orelhas, narinas ou órgãos sexuais visíveis, membros alongados ou desproporcionais e número de dedos inferior ao dos humanos.

Da mesma natureza que os monstros dos filmes de terror, os alienígenas são seres repugnantes - porque o aspecto físico é nauseante e ameaçador - e extremamente repulsivos, isto é, a sugestão do contato com o corpo estranho provoca gestos de esquiva nos apavorados terráqueos (Cf. CARROLL, 1999). O aspecto repulsivo não apenas provoca medo, mas também decodifica por meios semióticos a realidade interior, isto é, expressa por meio de uma linguagem visual as deformidades ou deficiências do pensamento e os defeitos morais desses seres. A monstruosidade física é, portanto, consequência de uma transgressão de ordem moral. A relação de equivalência entre exterior e interior é confirmada na observância de que, ao mesmo tempo em que dominam uma tecnologia superior ou desconhecida entre os homens, mostram-se criaturas bestializadas em seu comportamento social. Planeta Proibido (Forbidden planet, Fred M. Wilcox, 1956), por exemplo, elabora uma crítica interessante ao mostrar que civilização alienígena do Planeta Altair-IV - os Krell - foi completamente destruída por si própria uma vez que inteligências superiores também desenvolvem maior capacidade de destruição, especialmente ao liberar os monstros invisíveis do id, o lado primitivo e destrutivo do subconsciente. 
Fábula que sutilmente demonstra o quanto a civilização é bárbara e o quanto a barbárie é civilizada. Tal característica morfológica, portanto, é determinante dos outros traços do Outro sideral.

\section{ORGANISMOS PARASITÁRIOS}

Unindo as atividades de visitação, a sondagem militar para captura de prisioneiros e o acossamento predador, há o alien de caráter parasita. Essa qualidade distintiva de seres vindos de outro planeta faz uso dos humanos como instrumento para procriação e disseminação de sua raça, reduzindo-nos à mera função de organismos hospedeiros. Povoar o mundo com uma raça ou espécime considerada superior - fantasia também presente em narrativas de vampiros e zumbis - parece remontar às teorias do chamado darwinismo social, explicação biológico-política que serviria, mais tarde, de base para ideologias como a do nazismo. Vale lembrar que a procriação é uma forma de expansão da raça sobre os territórios e de submissão dos mais fracos e menos numerosos, premissa encontrada até mesmo em um dos livros da cultura judaico-cristã, o Gênesis (crescer - multiplicar - submeter).

Exemplificando a abordagem acima, $A$ aldeia dos amaldiçoados (The village of the damned, Wolf Rilla, 1960) é um filme sobre uma pequena cidade dos Estados Unidos, na qual um estranho fenômeno faz com que toda forma de comunicação seja interrompida e os habitantes da área caiam em uma espécie de torpor por algumas horas. Depois de terem a consciência retomada, nenhuma explicação satisfatória para o fato é encontrada. Mais tarde, descobre-se que as mulheres férteis haviam ficado grávidas naquele intervalo de tempo, o que sugere implicitamente uma violação sexual (ou, menos 
provável, a fecundação por algum "espírito santo" interplanetário). Os frutos de tal concepção eram crianças-monstros (em termos simbólicos, a gestação invasiva, alienígena e alienante é uma experiência similar à de um parasita ${ }^{8}$ ) de testa avantajada, olhos brilhantes, cabelo de loiro platinado, extremamente inteligentes e soturnas. Tão assustador quanto a paternidade desconhecida - algo que remete aos estupros de europeus a indígenas e ao processo de mestiçagem - são os poderes das enfants terribles, o que não impede de que estes "bastardos" sejam marginalizados pela comunidade local e temidos por seus moradores.

O trato entre humano e alienígena, no entanto, não se resume apenas a uma relação ecológica desarmônica que traz pequenos prejuízos ao hospedeiro, mas pode, e aqui surge o problema, acarretar dano definitivo: para o nascimento e a sobrevivência do parasita, é preciso condenar à morte quem inicialmente o hospeda. É o que acontece em clássicos como o de Ridley Scott, Alien - o oitavo passageiro (Alien, Ridley Scott, 1979), em que a parasita, o embrião alienígena, termina o amadurecimento no corpo do organismo hospedeiro e, uma vez nascido, o espécime leva à morte aquele que o hospedava. Ademais, no futuro previsto pela história dirigida por Ridley Scott, a corrida interplanetária neocolonial já aconteceu. Existem Administrações coloniais, Comissão Interestelar de Comércio, fuzileiros coloniais, oficiais androides (humanoides sintéticos) e instalações de terraformadores - características que implicam a leitura do parasitismo não apenas em seu viés biológico, mas também na sua realidade social e econômica, matriz do sistema capitalista e do imperialismo decorrente dele.

8 Para saber mais sobre a percepção da criança como um parasita, ver: CORSO; CORSO, 2011. 
A nave estelar dos protagonistas de Alien - o oitavo passageiro, retornando de viagem com uma carga de minérios, recebe uma transmissão de sinais acústicos vinda de uma nave alienígena no planeta LV-426, um lugar ainda não vistoriado na época. O contrato com os astronautas da nave comercial de carga Nostromo implicava - obrigatoriamente - a investigação de qualquer comunicação potencialmente proveniente de alguma forma de inteligência, descumprimento que seria punido com a perda sumária das cotas de extração de minério. Além de um paralelo possível com as viagens marítimas que levaram, por exemplo, ao achamento do Brasil pela frota de Pedro Álvares Cabral, importa salientar que Nostromo é o título de um romance de Joseph Conrad, publicado em 1904, fortemente marcado pela ironia quanto ao discurso imperialista, e focado na exploração de jazidas de prata na América Central. Assim, tendo uma nave que cria um diálogo com uma situação econômica e política do mundo colonial, o roteiro conecta o "imperialismo tradicional" ao moderno, combinando domínio tecnológico, interesse militar e poder corporativo.

Na visita de reconhecimento, um dos tripulantes da Nostromo é invadido por um parasita alienígena e, ainda que seja claro o potencial destrutivo da criatura, a nave recebe novas diretivas do computador central, A Mãe (sugere uma "maternidade" maligna porque desumana). A prioridade estabelecida é o retorno a Terra com o organismo para a análise, tornando secundárias todas as ações primárias iniciais - a de mineração e transporte - e fazendo da tripulação algo descartável. A Companhia (a falta de nome próprio cria por si só uma alegoria), um conglomerado colonizador associado aos militares, deseja o alienígena para a divisão de armas, 
sobretudo porque acaba sendo considerado um organismo perfeito em vista de sua característica estrutural e de sua hostilidade. O destino dos personagens significativamente é determinado pela frieza do oficial cientista, por sinal um androide, e pelo próprio computador da nave (a "Mãe") - símbolos da desumanização e da alta racionalização do ser humano diante dos progressos da modernidade, tanto em sentido econômico (conglomerado) quanto tecnológico (viagens espaciais de extração).

A monstruosidade capitalista ${ }^{9}$ está presente nos outros títulos da franquia: Aliens, o resgate (Aliens, James Cameron, 1986) explora o retorno da tenente Ripley ao planeta LV-426 depois de um hiper-sono de 57 anos, sob uma aparente missão de resgate de terraformadores que, no entanto, trata-se de uma busca da divisão de armas biológicas do elemento xenomórfico. Em Alien $^{3}$ (Alien ${ }^{3}$, David Fincher, 1992), depois de cair com a nave de fuga em um planeta-prisão, Ripley assume, como única mulher do grupo, o caráter de Eva/indutora da tentação e de Pandora/ libertadora do Mal. A Companhia, nesta trama, não deixará de interferir, visto que a tenente é hospedeira do embrião de uma rainha da hostil espécie alienígena. Para salvar o mundo de uma devastadora arma biológica, Ripley comete suicídio. Isto não a livrou de outra fantasia futura, a da clonagem genética, ocorrida duzentos anos mais tarde, em Alien - a ressurreição (Alien: ressurrection, Jean-Pierre Jeunet, 1997). Desta vez não há intermediários capitalistas, a Sistemas Militares Unidos, versão militar da ONU, é quem gerencia os produtos orgânicos. sob o ponto de vista da maternidade, considera também o predador monstro capitalista representado pela Companhia da ficção audiovisual. 
Ironicamente, no filme que fecha a franquia, é um androide feminino a mais interessada em salvar a raça terrestre tudo por ser "humana, demasiadamente humana".

Em outros casos, diferente do exemplo acima, o hospedeiro sofre um processo interno de subjugação ou mutação, sendo transformado lentamente em uma entidade alienígena. Se não o faz por fora, atendendo a qualquer princípio ardiloso de camuflagem, o parasita o faz inteiramente por dentro, reduzindo toda humanidade a zero. No caso de $O$ monstro do Ártico (The Thing from another world, Christian Nyby, 1951), uma estranha criatura é encontrada no gelo por cientistas e, depois de descongelada, devora o corpo de qualquer animal próximo, copiando suas células e transformando-se em uma cópia idêntica dele. Já na produção Domínio alien (Dark Breed, Richard Pepin, 1996), seis astronautas são "infectados" por algum tipo de obsessores espirituais alienígenas, de modo que se cria um estado esquizofrênico no qual se alternam a consciência humana e a consciência parasita. Esta forma anímica, com o passar do tempo, tomaria por completo o corpo do hospedeiro e metamorfosearia a realidade física dele de modo endógeno. 0 curta-metragem brasileiro $O$ hóspede (Anacã Agra e Ramon Porta Mota, 2011) engrossa a lista: pouco depois da repentina seca do açude velho, do avistamento de um objeto não identificado no céu e da epidemia de uma estranha doença (a gripe do cérebro), um estranho viajante - um alienígena doppelgänger de um ser humano - aparece em uma pousada no interior da Paraíba e, pouco a pouco, começa a duplicar os corpos de outros humanos e exterminar os originais. Além disso, a ficção dos diretores 
brasileiros critica no subtexto a intervenção norte-americana no caso - ao modo de uma invasão estrangeira - porque acaba por tratar o governo brasileiro como um incapacitado (uma "civilização inferior") para lidar com questões de segurança.

Em outra variedade, seguindo a premissa da comunicação interplanetária está A experiência (Species, Roger Donaldson, 1995), ficção que retrata a comunicação interplanetária a partir de duas mensagens enviadas de uma fonte desconhecida em resposta a informações básicas sobre a Terra. A primeira era benéfica (um catalisador para o metano) e, como se descobriu mais tarde, funcionou como camuflagem; a segunda, maléfica, continha instruções para combinação de DNA alienígena com genes humanos, algo que resultou em uma arma biológica - um predador híbrido que fazia uso da forma humana como máscara. Para multiplicar-se, este novo espécime aparecia com o corpo de uma linda mulher, literalmente uma femme fatale visto que, dada sua ontologia particular, o ato de copular tornava-se um tipo de fantasia sexual sinistra e mortal.

Na sequência dirigida por Peter Medak, A experiência II - $a$ mutação (Species II, 1998) o roteiro parece ser mais crítico em certos aspectos. Nele, um programa espacial do governo americano é o primeiro a aterrissar em território marciano, o que reafirma uma pretensa soberania norte-americana ("A América pode chegar aonde quiser", diz o presidente ficcional). No entanto, o primeiro homem a pisar em Marte é filho do senador (mais um jogador de futebol que um astronauta), transformado em herói pela mídia a despeito dos graves escândalos políticos envolvidos na escolha. Possivelmente é esta "herança", a de um sistema político corrupto 
apoiado no nepotismo e na mídia manipuladora, o que alegoriza a contaminação do pseudoastronauta por material extraterrestre, representando-o como uma maçã podre pronta para estragar as saudáveis de um caixa (o planeta Terra, no caso). As amostras do solo de Marte, nas quais havia DNA alien, revelaram que o planeta já havia sido habitável um dia, tendo sido devastado por um tipo de câncer ou peste - uma contaminação biológica catastrófica -, a mesma que estaria agora presente na Terra. Ironicamente, Eva é o nome da forma alien clonada do primeiro filme, o que implica a noção cristã do pecado original. O subtexto do filme explora um discurso inter-racial disfarçado, pois o código de ética humano é posto em crise diante de um ser meio humano e meio alienígena. Afinal, como lidar com a mistura de raças/espécies? Como sacrificar algo que também é humano?

A Experiência III (Species III, Brad Turner, 2005), de outra sorte, parte da premissa de que o que atraiu a atenção dos extraterrestres para Terra, com muitas evidências de visitação a partir da década de 1950, foi a explosão da bomba atômica. No entanto, mesmo não se sabendo claramente quais as reais intenções desses seres frios, indiferentes, insaciáveis "desumanos" e agressivos, um cientista xenônamo faz pesquisas escusas em seu laboratório na tentativa de produzir um alienígena com pedigree. É a abertura para uma metáfora da experiência científica fora de controle - a Terra como a ilha do Dr. Moreau - e, por ser única neste mundo, dada sua origem estrangeira, a versão alienígena do monstro de Frankenstein. Finalizando a franquia, A Experiência IV-o despertar (Species: The Awakening, Nick Lyon, 2007), de um modo precário, reinventa a fábula do Dr. Jekyll e Mr. Hyde, isto é, da espécie híbrida que não conseguia mais manter a 
forma humana com o auxílio de hormônios, dando lugar à sua forma mais sombria, a predadora alienígena, outro componente típico de representação extraterrestre como se verá.

\section{INSTINTO PREDATÓRIO}

Outra característica bastante comum na figuração do extraterrestre monstruoso é o espírito predador, segundo o qual o alienígena vê a raça humana em nível inferior na pirâmide alimentar, passível de tornar-se presa ou animal para práticas de caça esportiva. Depois que o cenário da cidade grande - a metrópole delineada a partir do século XIX - possibilitou o florescimento do gênero policial, no qual a cidade torna-se pavilhão de caça, na escala global da cidade-mundo, pode-se considerar que o alienígena faz dos espaços urbanos uma savana cosmopolita ao lançar sua ferocidade sobre a espécie nativa. Os subúrbios e os centros da cidade assumem, nesse tipo de safári intergaláctico, uma condição semelhante à da visão selvagem dos conquistadores sobre a América, África e Ásia. O perfeito predador da humanidade seria aquele que pode nos perceber como raça exótica, ou seja, só poderia mesmo ser extraterreno devido ao caráter pretensiosamente soberano que exercemos sobre a Natureza e em razão do modo como instituímos no mundo ocidental o conceito de civilização.

A narrativa mais emblemática da predação, por conter tal traço definidor no próprio nome do protagonista, é a ficção $O$ Predador (Predator, John McTiernan, 1987), na qual um ser vindo não se sabe de onde passa a matar seres humanos, aliando a uma incrível força variada gama de vantagens tecnológicas - como pistola a laser, visão infravermelha, sofisticada capacidade de camuflagem e um 
sistema de autodestruição atômico. O pano de fundo (político) do roteiro - gatilho que coloca a narrativa em movimento e estabelece possibilidades de interpretação comparativas - é o resgate de representantes do governo desaparecidos em uma selva mesoamericana, possivelmente sequestrados por guerrilheiros associados a militares russos. No centro da história, contudo, está o caçador extraterrestre pronto para sua temporada de captura de animais, na qual os crânios dos animais-homens são verdadeiros troféus de caça. O esporte do alienígena predador aos nossos olhos pode parecer repugnante, da mesma forma que, hoje, em vista dos valores ecológicos e do peso da ecocrítica, é moralmente censurável a caça aos animais por simples diversão. Mas o verdadeiro horror claramente repousa na tomada de consciência de que, aos olhos da criatura em questão, a raça humana é um animal como qualquer outro, e quem está no topo da cadeia alimentar sideral é o próprio ser extraterrestre. Além disso, tal predador alienígena realiza visitas frequentes à Terra, ocorridas nos anos mais quentes, tornandose naquele país não identificado da América Central uma figura folclórica: "el que hace trofeos de los hombres" ou "el diablo, cazador de hombres".

Na sequência dessa produção norte-americana, Predador 2 a caçada continua (Predator 2, Stephen Hopkins, 1990), o caçador sideral surge durante uma onda de calor em Los Angeles, em meio a brigas de gangues do narcotráfico (não por acaso entre jamaicanos e colombianos, isto é, estrangeiros/inimigos do Estado americano) e caçadas policiais. Além do calor, a narrativa nos informa que os predadores são atraídos por conflitos armados como os que já aconteceram em Hiroshima, Camboja e Beirute, isto é, potenciais 
antagonistas bélicos são fortes atratores. A grande metrópole, quanto a isso, pode muito bem ser vista como uma selva de criaturas predatórias. Já tendo sido identificado pelo governo americano, os agentes federais desejam capturá-lo para fins armamentistas, como também aconteceu em Alien - o oitavo passageiro. Na sala de troféus da nave espacial, aliás, há o crânio do alienígena de Ridley Scott, referência que dará brecha para um filme crossover de confronto entre as duas raças.

Criando uma sequência - ou mesmo uma história paralela - para a fábula original, está Predadores (Predators, Nimród Antal, 2010), ficção científica que acentua ainda mais as metáforas predatórias. A história trata de um grupo de humanos facínoras capturado misteriosamente e enviado a um planeta desconhecido. Não demoram muito para descobrir serem as presas da temporada; e o mundo no qual se encontram, uma reserva de caça gigantesca. A atividade de caça, conforme será observado, ordenava-se segundo uma pirâmide de força (ou mesmo de pirâmide alimentar), constituída por espécies diferentes de alienígenas e também pela própria espécie humana. Os humanos abduzidos concluem que, sendo um grupo composto por mercenários e assassinos profissionais, não foram escolhidos aleatoriamente, mas em razão do forte instinto predatório, monstrificação reforçada pela epígrafe do escritor Ernest Hemingway no filme: "Não há nenhuma caça como a caça ao homem. E quem já caçou homens armados por muito tempo e gostou, nunca mais se interessou por outra coisa depois disso" ${ }^{\prime 10}$.

10 No original: "Certainly there is no hunting like the hunting of man and those who have hunted armed men long enough and liked it, never really care for anything else thereafter". Extraído de On the blue water: a gulf stream letter, artigo de abril de 1936, publicado na revista Esquire. 
É possível depreender de enredos dessa natureza o quanto o ser humano teme ser perseguido e até mesmo destruído por uma categoria de seres que ignora por completo as leis vigentes e os direitos humanos - normas que não poderiam conhecer e nem (se importariam em) respeitar. $\mathrm{O}$ temor coloca em outra moldura eventos históricos semelhantes, o das invasões bárbaras ocorridas no século V, o das Cruzadas, o das Grandes Navegações, a Shoah. Se a humanidade considera um risco os excessos desta civilização - merecendo destaque as denúncias de abuso da ocupação norteamericana no Oriente Médio, ou o caos de matriz étnica, mas sobretudo comercial na África - que dirá o que pode vir de quem está, literalmente, acima dos dispositivos políticos planetários?

Logo, não parece de modo algum uma gratuidade da narrativa alienígena, visto que representa um dado importante da personalidade humana: o medo da aniquilação é introjetado no inconsciente na forma de um sentimento persecutório. Ao mesmo tempo em que a curiosidade impulsiona o desbravamento do universo, a insegurança gerada por possíveis formas de vida extraterrestres cria potentes fantasias de perseguição, atestadas por inúmeros documentos de viajantes europeus afirmativos da existência de monstros ultramarinos. Nelas, o alien é o duplo do homem, seu irmão gêmeo no universo, mas o irmão mau, com quem estabelece rivalidade pela posse de um território interplanetário. Ou seja, trata-se da temática mítica e universal do doppelgänger ${ }^{11}$, revestido de uma roupagem sideral.

Um filme que dramatiza tal componente persecutório é 11 Para analisar mais detidamente o caráter persecutório do doppelgänger, consultar Otto Rank (2014). 
Sinais (Signs, M. Night Shyamalan, 2002), no qual seres do espaço aparecem aqui para capturar espécimes humanos (experiências, diversão?) e não para tomar o planeta. A história do filme reacende antigos debates e temores acerca dos símbolos geométricos de grandes dimensões surgidos misteriosamente em plantações do mundo todo ao longo dos anos, os chamados crop-circles. Dentre os sinais mais conhecidos estão os geogrifos, localizados no deserto de Nazca, no Peru, que muitos creem ser instruções visuais para um campo de pouso alienígena. Não optando por uma versão cética do fenômeno, a de que seja uma elaborada prank humana, a narrativa cinematográfica opta por reforçar uma incerteza ancestral e um sentimento paranoico.

Gerada pela sensação de acossamento ou visitação extraterrena, a possibilidade de a Terra receber (ou ter recebido) hóspedes intergalácticos foi bastante estimulada por polêmicas da seara de Eram os deuses astronautas, de Erich Von Däniken, obra publicada pela primeira vez em 1968 e consumida como um bestseller da ufologia até hoje, ainda que suas teorias tenham sido, ao longo dos anos, duramente criticadas por especialistas. Segundo a argumentação do autor, espécies alienígenas, astronautas extraterrestres, teriam fundado civilizações avançadas, possivelmente a dos egípcios e dos incas, e seriam recordados por esses povos como deuses. Nesse caso, as pirâmides, os símbolos de Nazca e os moais da Ilha da Páscoa seriam possíveis vestígios desses viajantes espaciais em nosso planeta. Talvez estas pudessem ser marcas de turistas de outro tempo, visto que há quem defenda que homens do futuro voltam ao passado para coletar informações históricas sobre séculos anteriores ou 
mesmo fazer do pretérito um curioso tipo de parque temático - a chamada hipótese interdimensional ou ultraterrestre. Vale lembrar que H. P. Lovecraft escreveu contos - tais como Dagon (1917), O chamado de Cthulhu (1926) e O assombro das trevas (1935) nos quais aparecem crípticos megálitos, fetichismos rituais e cultos míticos e sombrios a deuses extraterrenos, existentes éons atrás, antes mesmo da infância da humanidade. Conjunto de histórias que explora com bastante destreza a categoria de horror cósmico criada pelo escritor norte-americano.

Retomando Sinais, pode-se dizer que o estrangeiro sideral, elemento externo à vida dos protagonistas, é base para o que a teoria do roteiro convencionou chamar "narrativa ritual" - os invasores alienígenas penetram no mundo cotidiano do personagem e modificam a dinâmica de suas relações - ao contrário das "narrativasjornada" - aquelas em que o personagem parte em busca de algo em um mundo considerado especial, diferente do cotidiano. Assim, no filme de M. Night Shyamalan, o que está em questão é a retomada da fé, algo proporcionado por essa presença estrangeira, portadora de sinais de revelação. A narrativa cinematográfica, apesar de não oferecer grandes aparições de seres alienígenas na tela, consegue construir um espaço de tensão claustrofóbica ao centrar-se na história de uma pequena família rural, procurando não desviar a atenção do espectador de signos mais importantes que o ataque espacial: as marcas do destino e sua recognição como prerrogativas para existência da fé. Os espectadores são tentados a acreditar, então, que Deus é sempre aquele que está em outro lugar, quem sabe em outro espaço-tempo: a divindade alienígena ${ }^{12}$. 


\section{CONTRAPONTOS: SALVADORES ALIENÍGENAS}

Uma característica positiva, pouco enfatizada nas narrativas alienígenas, é a do exilado, atribuído a uma categoria de seres que, por alguma razão, voluntária ou não, precisaram ser expatriados do seu planeta de origem, vagando por um território do não pertencimento. Em $O$ homem que caiu na Terra (The man who fell to Earth, Nicolas Roeg, 1976), um alienígena deixa sua morada extraterrena e sua família para descobrir um meio de levar água ao seu planeta. Vivendo sob o disfarce de um homem de negócios, torna-se um dos maiores bilionários globais por conta das invenções patenteadas e da multinacional criada para, assim, reunir recursos financeiros suficientes para custear um projeto espacial e desenvolver um sistema de transporte de água. Entretanto, ainda que tenha o sonho de retorno ao lar, este estranho estrangeiro será desviado de sua tarefa por forças cruéis dos terráqueos - a disputa corporativista e a rivalidade tecnocrática, o poder alienador da televisão e o vício do alcoolismo. Além de apresentar o alienígena como alguém que sente saudades da morada e um hóspede indesejado pela sociedade capitalista, ao longo do filme cria-se um laço sutil do extraterrestre caído (de fato, "caiu"/aterrissou na água) com a do mito de ĺcaro por meio do quadro de Pieter Bruegel, o velho (Paisagem com a queda de Ícaro, 1554-5), expressando a ideia de alguém que irá perder-se.

Outro alienígena, este originário dos quadrinhos e particularmente famoso, também assume a imagem do expatriado: o Super-homem. Vindo do planeta Krypton, antes que uma explosão atômica o extinguisse por completo, Kal-El 
chegou à Terra, junto com uma tempestade de meteoros, e foi criado por pais humanos. Com exceção dos incríveis poderes que o diferenciam, o Super-homem é idêntico a qualquer um de nós: também foi concebido no seio de uma família e possui defeitos e qualidades essencialmente humanos - amor, ciúmes, tristeza, solidão. A mitologia em torno do herói basicamente o trata como um tipo de Messias, um salvador para o nosso mundo, como fica bastante patente na sequência Superman - O retorno (Superman Returns, Bryan Singer, 2006), especialmente nas imagens de divulgação do filme, alusivas à figura crística.

Se ficções como $O$ homem que caiu na Terra são um modo de representar o olhar do alienígena a respeito dos humanos, é possível constatar que se tratam de narrativas que fazem do extraterrestre um duplo humano. É a humanidade fazendo uso de uma máscara ficcional para elaborar uma crítica a si mesma por meio de um jogo metafórico de espelho e duplicação. Os aliens não incorporam apenas o lado negativo do ser humano - ou sofrem nas mãos dele -, pois também podem ser aqueles a nos alertar sobre um possível destino apocalíptico caso insistamos em um caminho destrutivo. Os terráqueos, então, seriam o irmão Mal do espaço sideral.

Dentre as histórias dessa ordem - associadas a um contexto político real - está $O$ dia em que a Terra parou (The day the Earth stood still, Robert Wise, 1951). O filme foi lançado durante o período da Guerra Fria, no qual o mundo vivia tensões e desconfianças por conta da divisão do globo em dois polos de influência, os EUA e a antiga URSS. Klaatu, o visitante extraterrestre, deseja alertar todas as nações sobre a possível destruição da Terra caso a agressão atômica constitua uma ameaça à paz interplanetária. Sua missão é 
neutralizar o perigo representado pela humanidade, especialmente se em interação com outros espécimes do sistema solar. Da mesma forma que E.T. ou Super-homem, Klaatu incorpora a imagem do Messias ao vir a Terra com uma mensagem de amor, operar um "milagre" (todas as formas de energia foram neutralizadas e imobilizaram o mundo por meia hora), sofrer um tipo de crucificação e morte, para depois ressuscitar e subir novamente aos céus depois de disseminar a verdade. Outras semelhanças com as narrativas bíblicas podem ser apontadas: o fato de a mensagem alienígena precisar ser entregue a todas as nações recorda o objetivo de Jesus e a profecia do livro do Apocalipse; o desejo de Klaatu caminhar entre os homens para conhecê-los e compreendê-los rememora a vida do Filho de Deus; e o pseudônimo assumido para misturar-se entre os humanos - Carpenter (em português, significa carpinteiro) - recupera a profissão atribuída a José, pai de Jesus na Terra.

Afora estas questões simbólicas, a própria diegese aponta para elementos referenciais, seja a fala do secretário do presidente dos EUA indicar a impossibilidade de um encontro amigável entre as nações, inclusive da ONU, devido às conjunturas políticas do período e à falta de precedentes para tal debate planetário; seja o comentário de uma das moradoras da pensão onde vive Klaatu de que o alienígena seria terrestre, isto é, algum agitador comunista de Moscou. A humanidade, a despeito do contato inicial amigável, se sente ameaçada pela presença do alienígena e deseja caçá-lo como se fosse um animal selvagem, o que perfaz o caráter predador do ser humano trabalhado anteriormente. Klaatu parece ameaçador por ser intolerante com a ignorância terrestre, especialmente com relação à violência bélica e ao emprego de energia atômica 
para destruição em massa. Das armas rudimentares às bombas atômicas aplicadas a mísseis, segundo o parecer do visitante, logo a humanidade constituiria uma ameaça não apenas a si mesma, mas a outros planetas, razão pela qual poderia ser atomizada pelos robôs-policiais do universo, representados pelo companheiro de viagem Gort.

O remake de $O$ dia em que a Terra parou (The day the Earth stood still, Scott Derrickson, 2008) atualiza uma série de relações apresentadas no filme original e torna Klaatu agente destruidor representante de um grupo de civilizações. O que fica em evidência não é o problema armamentista da década de 1950, mas o descaso para com o meio ambiente nos últimos séculos. É uma produção que resulta dos debates acerca da preservação da natureza e do desenvolvimento urbano e industrial surgidos, por exemplo, em Estocolmo-72, durante a Eco-92, com o Protocolo de Kyoto. Assim, apoiado no discurso da sustentabilidade, isto é, do equilíbrio entre sociedade, economia e meio ambiente, Klaatu declara-se um amigo da Terra e não da humanidade, de modo que a extinção de nossa raça seria condição necessária para que não ocorresse o absurdo de uma só espécie destruir levianamente um planeta inteiro. Repetindo a fórmula do visitante extraterreno como um tipo de Messias e de instrumento da ira de Deus, encontramos no filme pequenos milagres - como o de reanimar um policial recém-morto ou "subir aos céus" - e a fábula da Arca de Noé - antes da aniquilação apocalíptica da raça humana, diferentes espécies de animais foram coletadas ao redor do globo e mantidas em segurança.

Diferentemente da versão anterior, de Robert Wise, não há diálogo com os representantes da ONU, tampouco com os representantes 
mais importantes da ciência, tudo porque, como forma de crítica, a Secretária de Defesa dos EUA dá a entender que representa todos os governos mundiais. Esse aspecto é sintomático, pois se apresenta como metonímia da visão política daquele país, vendo-se como uma espécie de regulador universal. Característica que se repete em outros filmes de extraterrestes e, mesmo em outros gêneros, como os de catástrofes. Em uma visão mais crítica, essa postura deixa ver a prepotência com que os EUA se posicionam discursivamente, por meio do cinema, a respeito de sua função no mundo atual, postura esta que contrasta com a ingenuidade de que o mundo aceitaria esta tutela, que não deixa de ser uma versão "moderna" do pensamento colonialista do século XVI - isto é, o neocolonialismo.

É por intermédio da Secretária de Estado que encontramos a ressonância da história humana nesse contato, pois, como ela explica à sua equipe, via de regra, no encontro entre civilizações a menos avançada delas é exterminada ou escravizada - como nos exemplos de Francisco Pizarro e os Incas, Hernán Cortés e os Astecas ou Colombo e os índios americanos. Constatando de imediato nossa posição fragilizada, após os satélites de defesa terem sido invadidos e os mísseis de ataque desativados, não haveria outra solução senão submeter-nos. Nesse caso, a perda da supremacia tecnológica e militar corresponderia à posição de inferioridade civilizacional. E esta é a lição que somos obrigados a amargamente aprender: o ser humano apenas tem a capacidade de mudar diante da catástrofe, à beira do precipício.

Klaatu percebe essa capacidade de mudança, nosso lado não destrutivo, e interrompe o processo de dizimação da espécie humana, mas parece nos deixar uma pergunta: como sobreviver 
ao período de crise no desenvolvimento de uma civilização? Não conseguiremos adotar um novo modo de vida antes da chegada da crise? Como identificar as ameaças verdadeiras? Será apenas uma força externa que poderá conter o potencial devastador do ser humano frente ao uso irracional da tecnologia? Se Klaatu tenta convencer os humanos sobre a progressividade dos feitos negativos da história humana, os alienígenas de Plano 9 do espaço sideral (Plan 9 from the outter space, Ed Wood, 1956) procuram impedir a descoberta de uma poderosa arma imaginária - a bomba solobonite - que poderia levar a uma pulverização interplanetária irreversível, por ser muitas vezes mais potente do que qualquer outra, referência óbvia à bomba atômica e à bomba-H, e ter a capacidade de destruir o próprio Sol. Contra o que consideravam um artefato bélico derivado da estupidez humana, a ofensiva programada pelos aliens pretendia levantar um exército zumbi das covas terrestres para dominação de todas as capitais do mundo. O plano fracassa, mas a mensagem é clara: a história é uma denúncia à selvageria e à insensatez das guerras, especialmente daquelas movidas pela bandeira de uma nação que se vê ameaçada por outra ou que se percebe superior a estrangeira, com direitos autodeclarados para destruir o outro para se salvar ou se manter soberana. Nesses exemplos moralizantes, a raça alienígena pode assumir a função de um psicanalista, uma entidade não envolvida diretamente nas instituições e ritos de uma sociedade, mas que pode mostrar o que ninguém consegue perceber e que precisa ser desentranhado da biografia humana: a arbitrariedade das leis e das verdades nas relações entre as nações. Se alguém olha por nós, na imensidão do espaço, não é apenas o que poderíamos chamar 
de Deus, mas também uma legião estrangeira também conhecida como alienígenas - agentes exógenos para problemas internos.

\section{INVASOR IMPERIALISTA}

Por fim, a mais usual marca do comportamento monstruoso do alien é a de invasor, o que torna as ficções alienígenas fraternas ao gênero de guerra. Ao contrário do que a ufologia frequentemente caracteriza como uma simples visita exploratória, o cinema estimula a ideia de um contato hostil de ocupação, de tentativa de tornar o planeta Terra uma "residência secundária" dos extraterrenos. Em muitas das histórias de invasão alienígena, tais seres, depois de esgotarem suas fontes de recursos naturais e de transformarem seu próprio planeta em um lugar inóspito (ou de sofrerem morte coletiva por causas terríveis ou mesmo por estarem à beira da extinção), vasculham as galáxias em busca de outro para ser tomado. Como invariavelmente é o planeta azul que aparece no caminho, esta figuração da ficção científica permite a substituição imaginária dos atores envolvidos na base ideológica do colonialismo (colonizadores e colonizados) por nos colocar no lado mais frágil da dinâmica.

Note-se que os alienígenas não desejam coexistir ou viver em harmonia com os humanos, querem tomar o planeta e destruir a toda raça nativa, seja para conquistar ou para destruir o Mal (o retrocesso, o primitivismo, a barbárie) que nossa espécie representa. Desejam imperativamente a dispersão dessa civilização inferior e o massacre da humanidade, o que nos remete a imagens bíblicas e mitológicas de ordem divina, tal como o Grande Dilúvio. Nesse ponto reside uma diferença importante em 
relação à experiência cultural humana: nossas formas históricas de colonização sempre acabaram, em diferentes graus, por absorver o Outro, ainda que à custa de destruições físicas e simbólicas; a colonização alienígena é tão somente destrutiva e aniquiladora. É a lógica da extinção e do extermínio genocida. Por isso, o efeito é de um duplo choque - ao mesmo tempo em que a humanidade tem conhecimento de outras civilizações além-Terra, desestabilizando determinadas certezas, descobre-se que nosso mundo é alvo de um desejo de apropriação brutal.

Críticos apontam a produção norte-americana $O$ homem do planeta X (The man from planet X, Edgar G. Ulmer, 1951) como um dos fundadores das modernas histórias de invasão alienígena. Segundo a história, um planeta desconhecido aproximava-se rapidamente da Terra sem, contudo, oferecer risco de colisão direta, apenas efeitos provocados por alterações atmosféricas (furacões ou maremotos). A princípio, o contato com o primeiro visitante parecia amistoso, mas um inescrupuloso cientista decide torturar e matar o alienígena tão logo revele seus conhecimentos tecnológicos, aqueles que o permitiriam controlar a indústria de materiais no mundo, condições que alteram o caráter complacente inicial. O visitante, entretanto, por meio das armas disponíveis, começa a transformar os habitantes do vilarejo escocês em zumbis obedientes e, com isso, preparava uma invasão alienígena. Afinal, seu planeta natal estava congelando e os seres de sua raça, para sobreviver, precisavam escapar do seu planeta moribundo e tomar outro.

Curiosamente, a forma de comunicação empregada em $O$ homem do planeta $X$ foi a matemática, por ser considerada de conhecimento universal e a linguagem mais pura da ciência. Seja como 
for, contrariando o mais que parodiado cumprimento tradicional, "saudações, terráqueos", os seres extraterrestres desconhecem acordos políticos ou diplomáticos e gozam de uma segurança invejável, talvez porque o esgotamento dos recursos naturais seja sinônimo das palavras avanço, progresso e evolução. Por isso, conhecendo de antemão a "inferioridade" da tecnologia humana ou sondando nossos hábitos "primitivos", especialmente pela interceptação dos nossos sinais de satélite, tão logo chegam às fronteiras do planeta azul, atacam. Em algumas variantes, no vácuo espacial, conectamse aos nossos satélites, absorvem todas as informações militares sobre nosso mundo e interferem nos nossos meios de comunicação e segurança. Os aliens têm certeza de que sairão vencedores como se este fosse o resultado óbvio do seu modelo de ação militar predador; o fato de muitas vezes conseguirmos derrotá-los não significa que sejamos mais fortes que os invasores, apenas que tivemos uma conjuntura bastante favorável a nós.

Na produção japonesa Monstros do Espaço (Chikyû Bôeigun/ The Misterians, Ishirô Honda, 1957), a história dos Mysterians serve de exemplo para a Terra. Depois de explodir o próprio planeta em uma guerra nuclear, os poucos sobreviventes do planeta Mysterioid, antes escondidos em Marte, vieram até aqui com falsas intenções de negociar a ocupação de um território para refugiados. Além de pretender tomar o planeta à força, com a ajuda de um enorme robô, eles visavam disseminar sua raça violentando as mulheres terrestres, constituindo a miscigenação o único modo de impedir o nascimento de crianças deformadas pela radioatividade.

Operando crítica semelhante, o mexicano $A$ nave dos monstros (La nave de los monstruos, Rogelio A. González, 1960), a nave 
alienígena, tripulada por duas mulheres e um robô, tem a missão de capturar espécimes machos com as quais as fêmeas possam cruzar. A miscigenação forçada acontece porque todos os homens de Vênus haviam sido dizimados pelo efeito da bomba atômica ${ }^{13}$, o que confere um efeito moralizante quanto ao uso de armas nucleares. Já no cult americano Frankenstein contra o monstro espacial (Frankenstein Meets the Spacemonster, Robert Gaffney, 1965), a princesa Marcuzan e sua tripulação estão à procura de fêmeas para repovoar seu planeta natal, destruído por uma guerra nuclear, além de desejar subjugar os habitantes da Terra. Vale dizer que nesta história, o monstro literário criado por Mary Shelley é definitivamente batizado como Frankenstein, mas, incorporando aspectos do contexto histórico do filme, é um tipo ciborgue, chamado coronel astronauta Frank Saunders, e projetado para viajar em uma missão até Marte, de modo a não colocar em risco vidas humanas.

O roteiro de Ishirô Honda, em vista do contexto históricopolítico no qual está inserido o filme, reverbera o trauma japonês quanto aos efeitos do ataque americano a Hiroshima e Nagazaki, representado pela fábula do monstro Godzilla, metáfora sobre os efeitos da radiação. Além disso, estabelece outro elemento narrativo importante: o confronto simbólico entre seres de dois

$13 \mathrm{Na}$ abertura do filme o narrador dirige-se ao espectador nos seguintes termos: "Isto é um átomo. Este é o Universo. Um átomo é infinitamente pequeno. O universo é infinitamente grande. Todavia, tudo é regido pelas mesmas leis. O homem aprendeu a liberar o poder do átomo e com isso quer conquistar o universo, mas o sonho de deixar a Terra e plantar sua semente num distante planeta, talvez com o desejo inconsciente de começar uma nova raça, os mesmos que estão a fabricar bombas atômicas e as guerras. E aqui está um planeta conhecido de nós. Vamos até ele, em uma característica noite de Vênus. Uma noite no qual eles estão organizando o mais importante voo planetário de sua história". 
estágios civilizatórios diferentes. Segundo os próprios alienígenas, os Mysterians já haviam desenvolvido a bomba-H quando nós ainda atravessámos a passo lento a Idade da Pedra. Contudo, os mísseis nucleares são vistos como "monstruosos", assim como as próprias heranças-monstro fictícias dos ataques factuais do qual Godzilla é um ícone ímpar.

Ao questionar a representação tradicional do invasor, o filme Os escolhidos (Dark Skies, Scott Stewart, 2013) versa sobre a abdução e apresenta a ideia de que a ocupação não se dá por uma ordem territorial, constituindo muito mais um campo de exploração científica dos alienígenas. Assim, ao contrário do imaginário que representa os visitantes como destruidores de monumentos e saqueadores de recursos naturais, eventos que sempre originariam um grande cataclismo no espaço terrestre, a entrada alienígena neste planeta ocorreria em virtude do desejo de nos estudar minuciosamente sendo, portanto, uma presença silenciosa, discreta e consolidada há muitos anos. O controle não se daria por ordem territorial, mas a nível mental, por meio de implantes de algum tipo de microchip naqueles que estão tendo um encontro de segundo, terceiro e/ou quarto graus. Além disso, contestando a noção de escolhido como algo especial, o ufólogo desta narrativa cinematográfica nos compara a cobaias de laboratório, a ratos querendo uma resposta do cientista que lhes causa males a fim de coletar dados para pesquisas científicas. Somos, assim, confrontados com uma franca decepção por descobrirmos que a origem do acossamento não residiria em certa qualidade singular de nossa espécie, bem como em nenhuma característica extraordinária dos abduzidos - os corpos humanos explorados por 
aliens seriam tão aleatórios quanto descartáveis. Nesse âmbito um duplo terror se procede: o de ordem extraterrestre, associado às fantasias de submissão por seres de outro planeta, e o de ordem política, centrada no medo de aprisionamento, tortura e controle por alguma autoridade incoercível e despótica.

Tal determinação do invasor revela outra característica importante: a da prepotência. O alien não sente necessidade de lutar pela ascendência em relação à espécie humana, pois se considera hierarquicamente superior na escala dos seres, e se obriga ao exercício pleno de suas funções de perseguidor, pronto para dizimar uma espécie inferior e afirmar sua soberania. É como uma nova (e intergaláctica) versão do Destino Manifesto estadunidense. Traçando um panorama geral, prevalece o alienígena como aquele que se considera em lugar elevado na escala civilizacional em relação aos humanos, aos menos no que diz respeito à tecnologia - sua capacidade de cruzar muitos anos-luz no espaço é prova cabal disso. Tal preeminência nada tem a ver com o impulso criador divino. O alien, acompanhando tais representações, seria um tipo de refugo vivo do irracional, aberto tão somente para o lado destrutivo da essência. Souberam pensar sua tecnologia por meio de uma linguagem aquém da compreensão humana - já que os extraterrestres, antes de qualquer possibilidade de tradução, só emitem gemidos guturais ou impulsos elétricos em suas cabeças de néon -, e se interessam unicamente pelas necessidades de seus impulsos negativos. São monstruosos, facínoras, sanguinários, desintegradores de matéria - representação da parte maldita da natureza humana. Seu ponto fraco, por conseguinte, está exatamente naquele que é apontado 
como um dos piores pecados capitais: a soberba. Apesar de não contar com armas tão avançadas para conter o avanço alienígena, devido à solidariedade, à astúcia, à inteligência ou mesmo à intuição e à sorte, o ser humano sempre consegue derrotar o invasor. O alien, cego em sua sede de poder, incapaz de pensar além da animalidade, é derrotado, expulso, destruído.

O cult britânico A Garota diabólica de Marte (Devil Girl from Mars, David MacDonald, 1954) trata de uma alienígena, vestida com sensuais roupas de vinil, que veio ao planeta para recolher espécimes masculinas para salvar a raça de seu planeta. No entanto, logo no primeiro contato, a viajante espacial expressa decepção pelos homens da Terra, considerando-os fisicamente pobres. Nyah, como é chamada, informa que em seu lugar natal as mulheres venceram uma literal guerra dos sexos e os homens são sujeitos a elas, o que acabou por fazê-los entrar em declínio e, consequentemente, levar à queda das taxas de natalidade. O destino da aterrissagem era Londres, mas por avarias na nave ao penetrar em nossa atmosfera, o pouso aconteceu em um vilarejo escocês, onde instala o terror nos personagens ligados a uma pequena pousada. Como demonstração presunçosa de sua superioridade tecnológica, a alien informa que sua nave espacial tem capacidade de autorregeneração, ou seja, o metal inorgânico possui propriedades orgânicas. Além disso, a nave possui um raio paralisador de amplo alcance; e a visitante, a capacidade de criar paredes invisíveis, de repelir ataques com armas de fogo, uma arma de raio-laser e a escolta de um robô gigante, Chani, quase uma versão feminina e hostil do Gort de $O$ dia em que a Terra parou (The day the Earth stood still, Robert Wise, 1951). No alto de sua prepotência, considera a ciência terráquea 
completamente primitiva, sobretudo porque a bomba atômica marciana é mil vezes superior em relação àquela que teríamos desenvolvido à época. O mote do seu esnobismo é dizer que nossa ciência ainda não descobriu, não significa que seja impossível. Por fim, a espaçonave e a turista espacial são destruídas com os "truques infantis" de seus cativos.

O uso da violência bélica como forma de autoridade é uma crítica presente em Tropas estelares (Starship Troopers, Paul Verhoeven, 1997), pois além de uma censura ácida às forças armadas americanas, ataca o sensacionalismo midiático e os filmes de propaganda política. O diretor declaradamente cria um diálogo paródico com obras de alto teor ideológico como O triunfo da vontade (Triumph des Willens, Leni Riefenstahl, 1935), documentário alemão de propaganda nazista no qual se constrói uma imagem heroica de Adolf Hitler, a fim de denunciar como o governo pode manipular a população a seu favor por meio do cinema. Talvez por isso, o filme seja bastante irônico ao colocar no papel de herói um argentino (por acaso a destruição de Buenos Aires é o estopim para o contraataque aos alienígenas), ao conceituar o cidadão como um soldado (um verdadeiro membro da federação, oposto ao "alienado" civil), ao apresentar oficiais americanos vestindo uniformes alusivos aos dos nazistas, ao narrar o massacre de americanos no ataque ao planeta dos insetos-aliens como resultado da prepotência que limitou qualquer estratégia efetiva (insetos seriam, a princípio, facilmente massacráveis) e de, possivelmente, sugerir que o planeta desértico dos inimigos era semelhante ao espaço geográfico do Oriente Médio pós-11 de setembro. 


\section{ARREMATE}

Como se pode concluir, com exceção das imagens positivas e messiânicas listadas anteriormente, o extraterrestre é símbolo da negatividade e rivaliza com ou mesmo representa o lado negro do ser humano. Os seres do espaço não parecem ser tão mais temidos quanto o foram ou ainda são os estrategistas de regimes totalitários, os imperialistas desbravadores ou, mais recentemente, os administradores de conglomerados multinacionais. 0 mito alienígena global e interplanetário deve ser encarado como símbolo de uma crise planetária. O significado original da palavra latina alienígena designa todo aquele que é natural de outro país, um estrangeiro ou forasteiro. Foi em virtude do frequente uso no cinema e na literatura de um sentido figurado que se tornou uma expressão popularmente conhecida para designar seres de outro planeta. A gênese da ficção alienígena repousa, ao que parece, em uma narrativa alegórica da história humana, muito a contragosto de H. P. Lovecraft, com articulação de componentes sociológicos e até psicanalíticos. É um composto bastante proteico para onde convergem mitos, ficções literárias, narrativas cinematográficas, crenças exotéricas, determinantes psíquicas e comportamentos sociais - componentes que funcionam, na maioria das vezes, como instrumento de denúncia e sátira política. E também um modo de indiretamente afirmar que os monstros são bastante reais, não pertencem às charnecas pestilentas, ao horror cósmico, aos abismos profundos e às galáxias distantes, antes de mais nada, habitam um espaço reconhecível e um sujeito conhecido e cotidiano: beast within, human being. 


\section{REFERÊNCIAS}

ANDERSON, Benedict (2008). Comunidades imaginadas: reflexões sobre a origem e a difusão do nacionalismo. Tradução de Denise Bottman. São Paulo: Companhia das Letras.

BELLEl, Sérgio Luiz Prado (2000). "Definindo o monstruoso: forma e função histórica". In: Monstros, índios e canibais: ensaios de crítica literária e cultural. Florianópolis: Insular. p.11-22.

CARROL, Noël (1999). A filosofia do horror ou paradoxos do coração. Tradução de Roberto Leal Ferreira. Campinas, SP: Papirus.

CORSO, Mario; CORSO, Diana Lichtenstein (2011). "Um monstro no ninho". In: A psicanálise na Terra do Nunca - ensaios sobre a fantasia. Porto Alegre: Penso. ECO, Umberto (org) (2014). História da feiura. Tradução de Eliana Aguiar. Rio de Janeiro: Record.

GIL, José (2006). Monstros. Tradução de José Luis Luna. Lisboa: Relógio D’água.

HALL, Stuart (2011). A identidade cultural na pós-modernidade. Tradução Tomás Tadeu da Silva e Guacira Lopes Louro. 11. ed. Rio de Janeiro: DP\&A.

JEHA, Julio (org) (2007). "Monstros como metáforas do mal”. In: Monstros e monstruosidades na literatura. Belo Horizonte: Editora UFMG. p.09-31

KAYSER, Wolfgang (2009). O grotesco - configuração na pintura e na literatura. Tradução de J. Guinsburg. São Paulo: Perspectiva.

LOVECRAFT, H. P (2012). A cor que caiu do céu. Tradução de Guilherme da Silva Braga. São Paulo: Hedra.

(2012). "Notas sobre ficção interplanetária". In: A cor que caiu do céu. Tradução de Guilherme da Silva Braga. São Paulo: Hedra, 2012. p.87-96.

LOVECRAFT, H. P (2011). O chamado de Cthulhu e outros contos. Tradução de Guilherme Silva Braga. São Paulo: Hedra.

(2011). "Notas sobre a escritura de contos fantásticos". In: O chamado de Cthulhu e outros contos. Tradução de Guilherme Silva Braga. São Paulo: Hedra. p.153-158.

LOVECRAFT, H.P (2008). O horror sobrenatural em literatura. Tradução de Celso M. Pacionik. São Paulo: Iluminuras. 
MARKENDORF, Marcio (2015). "Os reflexos do colonialismo em narrativas alienígenas". Revista Gavagai, 2 (2), p.93-105. (2015). “A reiteração fóbica do estrangeiro". Revista Subtrópicos, 19, p.09. NAZÁRIO, Luiz (1983). Da natureza dos monstros. São Paulo: s/e. (1998). Da natureza dos monstros. São Paulo: Arte e ciência.

RANK, Otto (2014). O duplo - um estudo psicanalítico. Porto Alegre, São Paulo: Dublinenense.

TODOROV, Tzvetan (1983). A conquista da América - a questão do Outro. Tradução de Beatriz Perrone Moi. 2. ed. São Paulo: Martins Fontes.

VERNE, Júlio (2005). Viagem ao redor da Lua. Tradução de Vieira Neto. Curitiba: Editora Hemus.

VON DANIKEN, Erich (2011). Eram os deuses astronautas? Tradução de Else Graf Calmus. São Paulo: Melhoramentos.

WELLS, H. G (1985). Os primeiros homens da Lua. Tradução de Fernando Py. Rio de Janeiro: Francisco Alves. 